\title{
An Assessment of Students' Paragraph Writing Problems and Causes: The Case of General Tadesse Biru Secondary School Grade 10 in Focus
}

\author{
Abdela Gobena $^{1} \quad$ Ebissa Bekele ${ }^{2}$ \\ Wollega University, Institute of Languages Study and Journalism, \\ Department of English Language and Literature, Nekemte, Ethiopia, P O Box: 395
}

\begin{abstract}
The aim of this study was to assess students' paragraph writing problems and causes of General Tadesse Biru Secondary school grade 10 in focus. The researcher designed 3 research questions which were set to identify students' problems in writing paragraph, and causes. A descriptive case study design which contains both qualitative and quantitative method was used. Four EFL teachers were selected through availability sampling, whereas; 40 students were selected using simple random sampling technique. The study employed four data gathering tools: document analysis, questionnaire, classroom observation and interview. Analyses of written paragraphs were employed to identify the problems students commit in writing paragraph. Questionnaire and interview were designed to identify the major causes of the problems. Classroom observation was employed to assess the methods teachers use in teaching paragraph writing in the classroom. The data collected through document analysis, questionnaire and classroom observation were analyzed qualitatively and quantitatively whereas interview was analyzed qualitatively. The finding of the study revealed that almost all students have problems of identifying three parts of the paragraph and writing unified, coherent, and well organized paragraph. The major causes of the aforementioned problems were lack of proper word use, absence of appropriate teaching techniques, and lack of writing practice. Thus, all the concerned bodies were recommended to do their best to restore students' writing skill.
\end{abstract}

DOI: $10.7176 / \mathrm{JCSD} / 66-01$

Publication date:August $31^{\text {st }} 2021$

\section{Introduction}

Writing is one of the four basic language skills used in communication. Through writing, students promote their ability of sharing ideas, feelings, believes, attitudes and values. Murcia (2000) argues writing is one of productive skills, which contains a symbol and involves a complex process. In making good writing, we must use correct grammatical rules, choose right vocabulary, and consider coherence and cohesion. Almost every aspect of everyday life for common people was carried out orally. Business transactions, records, and legal documents, political and military agreements all were written by specialists. Today, the ability to write has become a key skill in our global literate community. The above points depicted that writing was not taking place when compared with speaking skills. Even though writing is very important issue to communicate, it was out of the game for long and all every day activities were carried out orally. Different scholars forward their views about how writing in English is difficult. According to Richard, learning to write either in the first or second language is one of difficult tasks a learner encounter (Richards, 1990, p. 100).

English language competence is a broad term with regards to writing which might include learners' grammatical competence, vocabulary mastery, and good organization of paragraph (Brown, 2004, p. 233). Lack of either grammar competence or vocabulary in particular, makes learners difficult to produce not only a paragraph but also a sentence, even. "Learners engaged in a productive task can become very frustrated when they just do not have the words or the grammar they need to express themselves" (Harmer, 2001, p. 252). As to Grisham and Wolsey (2011), "for many teachers, writing is the area of language arts that they feel themselves least prepared to teach well” (p. 348). In addition, the lack of writing instruction can then result in a lack of selfefficacy among students to use writing strategies. As to the above scholars, teaching writing is complex for most teachers. After observing certain classes during teaching writing process was on going, they observed as teachers were not teaching appropriately. Written products are often the result of thinking, drafting, and revising procedure that require specialized skills, which speaker can't develop naturally.

For the first time, the paragraph theory was primarily established in (1818-1903). The theory asserts that the paragraph is a unit of a piece of writing and generally consists of several sentences. A paragraph is a group of related sentences which a writer develops about a subject. The starting sentence explains the certain idea while the other sentences are stated to support it". They also explained that it is emphasized by identifying the first word from the left hand margin. Therefore, a complete paragraph is made of of three sorts of sentences: topic, supporting and concluding sentence.

Scholars pointed that, students whose L1 is not English often have significant difficulties with some aspects 
of English language in writing that are distinct from the problems that native speakers have. As Clifford (1987) states L2 learners of English face problems of exploring ideas and thought to communicate. According to Kharma (1986), learners have the problem of structuring the paragraph, topic development of a paragraph, structuring the whole discourse and a theme in a discourse. The other problem of organization in student' writing is the difficulty of differentiating a topic and supporting ideas or generalizations and specific details. Pincas (1982) has also showed that learners have the problems of writing united paragraphs because of their failure to use cohesive devices appropriately. Several studies discovered how much time students spent writing and then how much time was spent on writing instruction. Teachers need enough time to instruct students in writing and then the students need time to practice the skills they learned. In a survey by Cutler and Graham (2008) discovered that students only spend about twenty minutes a day on writing and teachers spend fifteen minutes on instructing their students in writing. In a similar study, Gilbert and Graham (2010) found that students in the participants' classes spent about two hours per week writing and then received about one hour and fifteen minutes of instruction per week.

As to Education and Training Policy of Ethiopia (1994) English is taught as a foreign language and a medium of instruction in secondary and tertiary levels. In Ethiopian context, teaching English is not as easy as teaching a native speakers. As a result, students cannot get the opportunity to practice writing outside of the classroom because their families and friends do not speak and write in English regularly. According to various sources, writing is a complex and difficult skill to teach and learn. Teachers and students face several problems in teaching and learning writing as a whole. Most of General Tadesse Biru secondary school students are incapable in writing paragraph in organized way. For this reason, based on the researcher teaching experience and informal observation, their performance in writing is very low when compared with other skills. This shows that there are problems which could be studied exhaustively.

\section{Objectives of the Study}

The general objective of the study is to assess the problems and causes that hinder grade 10 students' paragraph writing in EFL classroom at General Tadesse Biru secondary school. Accordingly, the specific objectives of the study were:

1. To identify the problems that grade 10 students face in paragraph writing

2. To find out the causes of the problems the students have in paragraph writing

3. To explore how teachers teach paragraph writing in the classroom

\section{RESEARCH METHODOLOGY AND DESIGN}

\subsection{Research Design}

To attain the intended objectives of the study, descriptive case study design which contains both quantitative and qualitative methods were used. Scholars argue research design is needed because it facilitates the smooth sailing of the various research operations, thereby making research as efficient as possible yielding maximal information with minimal expenditure of effort, time and money. To analyze and discuss the gathered data, the researcher used mixed methods which gives us greater confidence in our findings and increases the validity of the results. If we use multiple methods and they reveal similar information, we can be more confident in our conclusions. And if we find different results across methods we can learn a great deal from considering why the results differ, (Kalof, Dan and Deitz, 2008).

\subsection{Research Setting}

The study was conducted in General Tadesse Biru Secondary School which is found in A. A, Gulalle Sub-city, 09 District, Addis Ababa, Ethiopia in 2020. The reason why the researcher selected the school was due to the fact that, the school was newly launched and nobody conducted any research on students' paragraph writing problems till the current study was designed and conducted, so the researcher inspired to conduct the study to assess students' paragraph writing problems and causes. Moreover, the researcher has been working there; so, it is advisable to save time and gather data from the students and his colleagues closely and cooperatively.

\subsection{Samples and Sampling Techniques}

Literature claims that when population is pretty homogeneous, the amount of variation is less and so the sample can be smaller. Based on this view, the researcher took $40(25 \%)$ of 160 students via systematic sampling technique. The researcher took 4 Grade 10 English Language teachers of General Tadesse Biru Secondary School through availability sampling.

\subsection{Data Gathering Instruments}

3.4.1. Document Analysis

Analysis of written paragraphs was used to achieve the intended objectives. To collect actual data about 
students' paragraph writing, analyzing the written paragraphs was used to identify the common errors that students commit in paragraph writing. Document analysis is a technique, which generates valid and reliable data. With this view, the researcher prepared a checklist with 8 questions to analyze the written paragraphs. The purpose of this text analysis was to identify students' problems related to topic sentence, supporting sentences and concluding sentence. Second, the problems associated to qualities of a good paragraph like unity, coherence, cohesion, adequate development, and organization were critically analyzed and interpreted. Third mechanical errors such as grammar, spelling, punctuation and capitalization were analyzed and discussed well. To save time, the researcher prepared and wrote different topics on the chalkboard which was familiar with students' prior knowledge.

\subsubsection{Questionnaire}

In this study, the questionnaire was carefully designed to answer the $2^{\text {nd }}$ and the $3^{\text {rd }}$ objectives of the study. Taking the scholars views into consideration, the researcher prepared 16 items for students to identify the major problems affecting students' paragraph writing skills and to assess how teachers teach writing skills. The items 1-6 were presented with five point Likert scale ranging from 'strongly agree' to 'strongly disagree'. To maintain reliability of the questionnaire, the researcher used different tools and validation techniques. Kalof et al (2008) argue that validity is concerned with congruence, or a goodness of fit between the details of the research, the evidence, and the conclusions drawn by the researchers. Finally, the researcher analyzed the quantitative data quantitatively and quantitative data quantitatively orderly.

\subsubsection{Observation}

To observe the teachers' actual teaching of writing paragraph, classroom observation was carried out using a checklist to assess how teachers' teach paragraph writing. "Observations are useful tools for providing direct information about language and language learning, and it is the best data collecting technique for gaining insight into the subject in a natural environment" (Morrison, 2000 as cited in Dula, 2017). The researcher used overt type of observation where the subjects being observed knew that they were observed. The observation was intended to answer research question number 2, and 3. The researcher observed four selected sections while the actual classroom was taking place. Accordingly, the researcher observed writing sessions of four teachers, two times each, which made a total of 8 sessions, and during the observation, he made a tick mark based on the observation checklist. In addition, the researcher also triangulated the data sources to ensure reliability and validity of the instrument.

\subsubsection{Interview}

In order to triangulate data collected from questionnaire and classroom observation, 9 interview questions were designed and gathered from the respondents. The researcher decided to use this tool to obtain the views and opinions of the respondents and other unexpected idea about the issue under study that otherwise might not be obtained through other tools. Bryman (2012) claims interviews are more suitable for questions that require probing to obtain adequate information. Semi-structured interview is one that contains structured and unstructured sections with standardized and open type questions. Though suitable for quantitative data collection, interviews are particularly useful when qualitative data are required. Therefore, the researcher prepared the interview questions based on the results of the document analysis, students' questionnaire and the classroom observation. The interview was made to answer research question $2 \& 3$. Finally, the collected data from teachers' interview were analyzed, discussed and interpreted.

\subsection{Method of Data Analysis}

The gathered data were analyzed quantitatively and qualitatively to find out students' paragraph writing problems. Observation, interview and document analysis were analyzed qualitatively while, questionnaire data were analyzed quantitatively. On the bases of the data analysis, the findings and conclusions were drawn and recommendations were forwarded. 


\section{DATA ANALYSIS, DISCUSSION AND INTERPRETATION}

\subsection{Analysis of Students' Written Paragraphs}

Table. 4.1.1: Summaries of Students' Problems in Written Paragraphs.

\begin{tabular}{llll}
\hline \multirow{2}{*}{ No } & Classification of the problems & Number of problems from & $\mathbf{4 0}$ written paragraphs \\
\cline { 3 - 4 } $\mathbf{1}$ & topic sentence & Frequency & Percent $(\%)$ \\
$\mathbf{2}$ & supporting sentences & 37 & $67.5 \%$ \\
$\mathbf{3}$ & concluding sentence & 27 & $75 \%$ \\
$\mathbf{4}$ & Unity & 34 & $67.5 \%$ \\
$\mathbf{5}$ & Coherence & 31 & $85 \%$ \\
$\mathbf{6}$ & Clarity & 34 & $77.5 \%$ \\
$\mathbf{7}$ & adequate development & 36 & $85 \%$ \\
$\mathbf{8}$ & Organization & 38 & $90 \%$ \\
$\mathbf{9}$ & Grammar & 37 & $95 \%$ \\
$\mathbf{1 0}$ & Spelling & 39 & $92.5 \%$ \\
$\mathbf{1 1}$ & Capitalization & 16 & $97.5 \%$ \\
$\mathbf{1 2}$ & punctuation marks & 28 & $40 \%$ \\
\hline & In this & $70 \%$ \\
\hline
\end{tabular}

In this section, the paragraphs written by 40 students were analyzed with regards to the problems students make during paragraph writing. In this section the researcher discussed more about students' problems in paragraph writing to answer the first objective. The researcher prepared a checklist to identify how students open, develop and conclude the paragraph; and he analyzed the flow of ideas, logical order, organization, unity, coherence and clarity of the written paragraphs.

In order to check whether students know their problems they were facing in writing, the students were asked two questions (Q $1 \& 2$ ). In item 1, 62\%, 15\%, 12.5\%, 10\% reported 'always', 'sometimes, 'rarely' and never respectively. On item 2, many students agreed on lack of vocabulary, lack of organizing ideas, lack of using proper grammar, lack of identifying topic, supporting and concluding sentences, and spelling error were their challenges in writing. To triangulate this data, the researcher interviewed two teachers in which they replied that lack of vocabulary, organization of ideas, lack of appropriate grammar use were the major problems. So, as it can be seen from the data analysis, the major problems students face in writing paragraphs were lack of vocabulary, lack of organization and lack of language use.

\subsubsection{Problems Related to Parts of a Paragraph}

\subsubsection{Problems Related to Writing Topic Sentence}

To suspense the reader to read in attention, topic sentence or opening part is the crucial point in writing. But, most students wrote their paragraphs without topic sentence. Out of 40 students, $27(67.5 \%)$ of them wrote the paragraphs without topic sentence and unclear introduction. They simply write down their ideas without considering the opening points. For example, look at the following sample paragraph written by S11.

Televizion is very important example watch news, films, and dramas. In another ways, Televizion can afect our eyes, and ears. When waching it we can get informasion and education. We are happy and enjoy looking films, dramas. It is first disadvantage is students busy while looking different films and moves. The second disadvantage is we don't give attension for education. The third advantage is burning time. General looking televizion is good and bad.

As indicated in the above paragraph which was written by S11, the student wrote the topic sentence by saying 'Television is very important to watch news, films and dramas.' This is not topic sentence; it seems supporting sentences because the word 'television' is mentioned in detail by providing example even it is incomplete and senseless to read. This shows that many students cannot differentiate topic sentence from the detail points.

\subsubsection{Problems Related to Writing Supporting Sentences}

Supporting sentences are the sentences which explain the topic sentence. It should be more specific and developed by examples, justification and illustrations. Of the written 40 paragraphs, 30(75\%) of them wrote unclear and inappropriate supporting sentences which were not well developed and not detailed. Look the sample paragraph written by $\mathrm{S} 25$.

Television has many advantages in the world for human bings. First of all People can watch television get information from news. News can help us to know about world. Second is watching films, dramas and commedy. The third advantage is people learned different things from it. Television has many disadvantages like eye poroblems, teach us conflict, boxes, horror films. Generally, watching television has many advantages and disadvantages in the world.

As it can be seen from the above data analysis, many students could not write detailed and attractive supporting sentences. They simply listed its advantages and disadvantages without using transitional words, conjunctions and examples in the right way. From the above discussions, the researcher concluded that many 
students have no awareness about the ways of developing paragraphs.

\subsubsection{Problems Related to Writing Concluding Sentence}

The concluding sentence is like your topic sentence, leaves the reader with an overall impression of the paragraph's subject. Out of 40 written paragraphs, only some students wrote their paragraphs which have concluding sentence. $27(67.5 \%)$ of the respondents could not write the paragraphs with attractive conclusions. For instance, look this paragraph written by S30.

Water polution can be hapened in many ways. The first one is city garbage which can mak water dirty. For example. people are living in rural area are drinking pollution water and using for different things. The second one is industrial waste or chemical from different factars. When people and cattle drink and use dirty water they can die and sick. Generally, the plastics throws from different sorces in river, lakes, stream, ocean, and sea.

As it can be seen from the above data, many respondents have the problems of summarizing the ideas well. Here, he started with the word 'generally' but he couldn't summarize rather give another detail.

In general, as explained earlier, among 40 students, only $14(28 \%)$ of them wrote a complete paragraph. In contrary, $29(72.5 \%)$ of them could not organize their ideas into topic, supporting and concluding sentences respectively. Of the written paragraphs $25(62.5 \%)$ of them have no clear starting, supporting and concluding points. They simply jot down their ideas in paragraph forms without organizing their ideas into introduction, supporting, and concluding parts. Of all 2(5\%) wrote all the given topics in a paragraph. From the whole respondents $2(5 \%)$ of them didn't write about the given topics; they simply moved around and went out of the track. In line this, Raimes (1983) states the problem of organization in student' writing is the difficulty of differentiating a topic and supporting ideas or generalizations and specific details. From the above discussion, the researcher generalizes that students couldn't identify topic, supporting and concluding sentence. Therefore, in writing identifying three parts of the paragraph was their serious problem.

\subsubsection{Problems Related to Qualities of Good Paragraph}

Items 3, 4 \& 5, are related to problems that students commit during organizing their paragraphs. The written paragraphs have different problems related to organizing ideas. In this part, the researcher observed that many students lack organizing their ideas while writing the paragraphs. Among 40 students except 5(12.5\%) of them, nobody wrote well organized, logically arranged, and well linked paragraphs to one another. The vocabularies they used to construct the paragraphs were not this much attractive, clear and explain the required message. They wrote the same words repeatedly in a paragraph to explain the same ideas. From the written paragraphs 34(85\%) students wrote the paragraphs which did not have linkage to one another, illogically arranged and no flow of ideas between sentences.

\subsubsection{Analysis Related to Writing Unified Paragraph}

In writing, unity is very essential point which should be considered to deliver a message. If there is no unity in a paragraph it is difficult to manage the oneness of the topic. On this, Pincas (1982) showed that learners have the problems of writing united paragraphs because of their failure to use cohesive devices appropriately. Out of 40 written paragraphs $34(85 \%)$ of them have problem of unity. Here, a sample of written paragraph by S18,

Pollution is the process which water, land, and air contaminate by many things. There are water pollution, land pollution and air pollution. Water is used to drink people. If water add chemical, industry darti water and animals die in water so coled water pollution. Land pollution also when cows and animals die on land is coled land pollution. Air pollution is smoking from factor and industry in capital city. General water pollution, land pollution and air pollution can damege many things.

As indicated in the first paragraph, though the given topic was 'water pollution' the student wrote about pollution in general including water pollution, land pollution and air pollution. The way he attempted to narrate was not specified in to water pollution. The paragraph had problems as lack of unity, run on and spelling. It showed that many students did not understand how unified paragraph written appropriately.

\subsubsection{Analysis of the Problems Related to Writing a Coherent Paragraph}

Coherence is the quality of a paragraph which is needed to connect one sentence to another sentence using different transitional words/phrases and prepositions in a paragraph. Even though coherence is very important to explain our ideas in writing, many students did not write coherent paragraph on the analyzed papers. To support this, Johns (1986) stated that foreign language students often lack the ability to organize ideas in a way which is appropriate to produce a coherent paragraph. Of the written paragraphs $31(77.5 \%)$ of them did not use necessary conjunctions/discourse markers, prepositions and linking words properly. Here is the sample paragraph written by S39: "My school is very big. By guessing it is more than one hectar. It is grade 9 and 10. The students more than 600 hundreds. Grade 9 eight classes grade 10 eight classes total 16 classes. Girl student has two toilet and boy student has two toilet. General we have library and good compound in beitiful school." As observed from the analysis, the written paragraph was senseless because it has serious problems in using words, conjunctions and transitional words. This indicates that most students have no awareness about conjunctions, prepositions and linking words to write coherent paragraph. 


\subsubsection{Analysis of the Writing Problems Related to Clarity}

Clarity is the very important issue to be considered in writing a paragraph to transfer the intended message. To be said the message is communicated, it should be clear and legible for the readers. In this study, out of 40 students, $34(85 \%)$ of them wrote unclear paragraphs. Of the written paragraphs $15(37.5 \%)$ of them have poor hand writing. Their hand writings were not clear to read and understand their messages. Their paragraphs were full of repetitions fragments and lack of subject verb agreement. Here is a sample paragraph written by S39, "School is my learning and I like school. I have books, pens, pencils and bag. My teacher is like me and students. I learn English, afaan Oromoo mats, piziks, chemisitiry and so on. I am go to school by time by taxi. By break time I play football and handball with friends. I like my school, teachers and students general." This paragraph is unclear for it lacks clear introduction and conclusion and lack of conjunctions too. The paragraph was full of faulty sentences like run on and fragments.

\subsubsection{Analysis of Problems Related to Adequate Development}

Adequate development is the most important issues in delivering message through writing. In the process of writing the writer has to develop his/her paragraph giving different examples, justifications and illustrations. Though a paragraph should be developed in appropriate methods, 36(90\%) of the written paragraphs were inadequate. They did not give tangible examples, appropriate justifications and illustrations to make the paragraphs more acceptable. Here is the sample paragraph written by $\mathrm{S} 22$ :

Television is very important invention to transfer information throughout the world. It has many advantages and disadvantages for human beings. Advantages of television: is transfer information, it is watch films and dramas, know the good news and source of happy. Disadvantages of television: eyes problems, burn or killing time and conflict or horror films. Students cannot write homework assignment. General, television has many advantages and disadvantages for students. Television has so many advantages for human beings.

As indicated in above sample paragraph, the written text was inadequately developed. The student simply wrote what comes to her mind without using examples, justifications and illustrations. He didn't use any discourse markers and prepositions to connect ideas. The paragraphs have the problem of faulty sentences. This shows that many students could not write well developed paragraphs.

\subsubsection{Analysis of Problems Related to Organization}

Organizing ideas into different texts is the prominent issue which should be clearly stated in writing process. In this case, the written paragraphs are expected to tie together, linked in a logical sequence and smooth manner. So, to convey the reader, the paragraph should be well organized, clear, unified, adequately developed, and coherent. However, in this study, 38(95\%) of the written paragraphs were not organized well. There were no linkage, clarity, unity and coherency among the sentences in the paragraphs. As sample, look at the following paragraphs written by S3: "My school is very beatiful and good from Addis Ababa schools. It has many more classes with grade 9 and 10. It has many teachers, directors and gards. Our class have 52 students fimale 24 mele 28. In the school we learn English, Afan Oromo, maths, physics, History, Chemistry, ICT, civics, Geograph and so on. So, I like my General TadeseBiru School. “

As indicated in the above paragraph, the student made so many problems during writing their paragraphs. The paragraphs which were written by S3 have no clear introduction, supporting sentences and conclusion. It looks like listing something in series than organized paragraph. In addition, there were no conjunctions, prepositions, examples, justifications, unity, clarity, and coherence. In short, it is very difficult to understand message and to get the main idea of the text.

\subsubsection{Analysis of Cognitive Problems}

The cognitive problems in writing include punctuation, capitalization, spelling, content and organization. Items 7 , $8,9, \& 10$ are directly related to the cognitive problems that occurred in writing. In this study, the written 40 paragraphs were critically analyzed and evaluated in relation to grammar usage, spelling errors, problems of capitalization and punctuation marks.

\subsubsection{Grammar Problems}

Grammar is all about how words and sentences are arranged and structured in a given text. It communicates meaning as precisely as the writer wants to covey (Thornsbury, 1999). So without grammar communication is difficult. In this study, many students had problems of using correct grammar in their paragraphs. Of all $37(92.5 \%)$ of the written paragraphs have fully grammar problems. They simply used any verbs in any position without considering when, where, and how they were used during writing. The most common problems they made in their paragraphs were tenses, subject verb agreement, and problems of active and passive. For example, look at the paragraph below:

My school is locat in Addis Abebe. My school have grade 9 and grade 10 students. We have two sport place. one is football, two is vole ball. So I liked football and my friends Gadisa and Hailu are liked volleyball every day. I went to learn English language. My teacher give homework daily but some students are do the homework and some students are no write the homework. every day we went to 
school on bus. General I am like school very much every time. The school have many advantages for students.

As observed in the above paragraph by S6, the paragraph has serious problems of grammar usage as whole which detract message. To conclude, they have problems of tenses, subject-verb agreement, active and passive voice, persons, singularity and plurality, and spelling errors which different scholars (Tyner, 1987; Kharma, 1986) have mentioned.

Table. 4.1.4.1: Summary of Grammatical problems from sample paragraphs written by some students.

\begin{tabular}{|c|c|c|}
\hline $\begin{array}{l}\text { Types of grammatical } \\
\text { problems }\end{array}$ & $\begin{array}{l}\text { Examples or samples of problems } \\
\text { students commit }\end{array}$ & Should be written as \\
\hline \multirow[t]{2}{*}{ Muses words } & many more & many \\
\hline & it is very disadvantages for people & it has many disadvantages for people \\
\hline \multirow[t]{4}{*}{ Tense problems } & Went & Want \\
\hline & I liked & I like \\
\hline & pollution water & polluted water \\
\hline & Learned & Learn \\
\hline \multirow{5}{*}{$\begin{array}{l}\text { Subject-verb-agreement } \\
\text { problems }\end{array}$} & school have & school has \\
\hline & our class have & our class has \\
\hline & teachers teaches & teachers teach \\
\hline & plastics throws & plastics throw \\
\hline & teacher give & teacher gives \\
\hline Conjunctions & $\begin{array}{l}\text { homework assayment } \\
\text { films dramas }\end{array}$ & $\begin{array}{l}\text { homework and assignment } \\
\text { films and dramas. }\end{array}$ \\
\hline \multirow[t]{4}{*}{ Faulty-sentences } & If water add chemical, & If we add chemical into water, \\
\hline & Water is used to drink people, & people used water to drink, \\
\hline & $\begin{array}{l}\text { Televizion is very important } \\
\text { example watch news, films, and } \\
\text { dramas. }\end{array}$ & $\begin{array}{l}\text { Television is very important for us. For } \\
\text { example we can watch news, films, and } \\
\text { dramas. }\end{array}$ \\
\hline & $\begin{array}{l}\text { Grade } 9 \text { eight classes grade } 10 \text { eight } \\
\text { classes total } 16 \text { classes. }\end{array}$ & $\begin{array}{l}\text { Grade } 9 \text { eight classes grade } 10 \text { eight } \\
\text { classes total } 16 \text { classes. }\end{array}$ \\
\hline \multirow{2}{*}{$\begin{array}{l}\text { Problems of plurality and } \\
\text { singularity }\end{array}$} & two sport place & two sport places \\
\hline & has two toilet & has two toilets \\
\hline
\end{tabular}

\subsubsection{Analysis of Problems Related to Spelling}

In writing, using correct spelling to forward the required information basic. If a writer does not use correct spelling, the message might be changed. To support this, as Moats (2000), said poor spellers often have low motivation to write. Though it is very important to deliver messages with correct spelling, many students wrote their paragraphs with full of spelling problems. Of the written 40 paragraphs, 39(97\%) of them wrote the paragraphs with full of spelling problems. S33 wrote: "My school is very betiful in Addis Abebe. There are many students like femel and mele. We have two sport feilds. Theire are so many techers in the schools. The school has one libirar and one IT room. Theire is two tolets one is for girls and one is for boys. In conclusion, our school has many things like libirar, sport feilds, and tolets." As shown in the above paragraph, there are many words which were wrongly spelt. One of the most important criteria that learners must improve in paragraph writing is to spell the words correctly to convey meaning to the reader. English orthography is notoriously complex. We should not expect children to get it right from the start. O'Sullivan \& Thomas, (2007) said children should be reinforced to learn to spell effectively in English, they need to be trained to attend to both the sounds of words, their visual configurations and, the structure of words. 
Table. 4.1.4.2: Summaries of spelling errors written by some students.

\begin{tabular}{|c|c|}
\hline Wrongly spelt words & Should be written as \\
\hline Informasion & Information \\
\hline Moves & Movies \\
\hline Bings & Beings \\
\hline Happened & Happened \\
\hline Prolusion & Pollution \\
\hline Televishion & Television \\
\hline Commedi & Comedy \\
\hline Waching & Watching \\
\hline Problems & Problems \\
\hline Mak & Make \\
\hline Factors & Factors \\
\hline Sorces & Sources \\
\hline Coled & Called \\
\hline Damage & Damage \\
\hline Darti & Dirty \\
\hline Industry & Industry \\
\hline Beitiful & Beautiful \\
\hline Libirari & Library \\
\hline Invension & Invention \\
\hline Thurought & Throughout \\
\hline Canot & Cannot \\
\hline Advantags & Advantages \\
\hline Disadvantags & Hisadvantages \\
\hline Horror & Horror \\
\hline Gards & Guards \\
\hline Fimale & Female \\
\hline Mele & Male \\
\hline Eyesight & Eyesight \\
\hline Communicate & Communicate \\
\hline Frends & Friends \\
\hline Westing & Wasting \\
\hline Now & Know \\
\hline Languge & Language \\
\hline
\end{tabular}

\subsubsection{Analysis of Problems Related to Capitalization}

In writing process, using the rule of capitalization is important to identify names of country, person, and at the initial part of the sentences. To support this, Kroll (1991) claims that capital letters are useful for sentence initials, the beginning of important words, in topics, headings, etc. However, learners have problems in using capitalization properly. There are reasons for students' problems in using proper capitalization. Of all the written 40 paragraphs $16(40 \%)$ of them wrote the paragraphs with the problems of capitalization. For instance, S19 wrote the following, "My school is very large and clean. our school is located in addis ababa. my school has toilets, Library, stores and many classes. my school director is yohannes and my english language is clever. General tadese biru secondary school has many students in different classes. In all our school is very good and nice." As it can be seen from sample paragraph, there were many problems of capitalizations, punctuation and organization. So, correct capitalization use was also their problem. 
Table. 4.1.4.3: Samples of capitalization errors written by some students

\begin{tabular}{ll}
\hline Wrongly capitalized & Should be written as \\
\hline General tedese biru secondary school & General Tadese Biru Secondary School \\
\hline addis ababa & Addis Ababa \\
our school & Our school \\
my school & My school \\
Yohanes & Yohannes \\
Library & Library \\
English & English \\
First & First \\
One & One \\
Every & Every \\
Maths & Maths \\
Physics & Physics \\
Civics & Civics \\
\hline
\end{tabular}

\subsubsection{Analysis of Problems Related to Punctuation Marks}

In writing something in our mind, we have to use punctuations in different conditions. Simply jotting down what comes to our mind may not be communicated. So, there must be different punctuation marks accordingly. Carrol and Wilson (1995, p 191) state students' writing encounter punctuation problems as there are no universal rules of punctuation. In this study, some students wrote their paragraphs without using correct punctuations. Of the written 40 paragraphs $28(70 \%)$ of the students wrote the paragraphs which were not correctly punctuated. Sample paragraph written by $\mathrm{S} 26$.

Television, is the very important for all people in the world. It has many advantages, and disadvantages. First the advantage of Television is, showing different informations about the new things. Second we can watch films dramas and comed to make us happy. Third we learn everything like Educational Political Science and Languge. In another ways. Television has disadvantages firstly it affect our eyes when we see it so many times. Secondly when we watch films all day it wastes our time. The third when we watch it for very long time we have no attension for education. In general television very good material for human.

As it can be seen in the above paragraph, the paragraph has serious problem of punctuations like comma (,) and full stop (.). Here, he simply misplaced mechanics. Therefore, more than half respondents could not write well punctuated sentences. Hall (2001) found out that meaningful understanding of punctuation results from a combination of meaningful reading and writing activities, talk about punctuation, emphasizing the effect it produces, encouragement of an experimental approach, a well punctuated classroom environment.

\subsection{Analysis of Students Questionnaire Data}

This section commences 15 close ended and 2 open ended questions. This tool was used to answer the $1^{\text {st }}, 2^{\text {nd }}$ and $3^{\text {rd }}$ objectives of the study. The first part eight close ended questions were designed separately whereas the second part eight questions were designed in summary forms to identify the causes in related to students and teachers problems to make more brief and clear for readers.

Table 4.2.1: Students' awareness and understanding on their paragraph writing problems.

\begin{tabular}{lllllllll}
\hline No Item & & & $\begin{array}{l}\text { Frequency/ } \\
\text { Percent }\end{array}$ & Always & Sometimes & Rarely & Never \\
\hline 1. & $\begin{array}{l}\text { How often do you make problems in Frequency } \\
\text { paragraph writing? }\end{array}$ & & & 25 & 6 & 5 & 4 \\
\end{tabular}

In order to check whether students have awareness and understanding on the problems they commit in paragraph writing or not the above closed item was asked. Of 40 respondents, 25(62.5\%), 6(15\%), 5(12.5\%), and $4(10 \%)$ said 'always,' 'sometimes,' 'rarely,' and 'never' respectively. As it can be seen from the data, most students have understanding about their problems in writing paragraph. In contrary, some students believe that as they were wiring well organized and good paragraph without any problems. This indicated that many students knew that their paragraphs have problems.

Table 4.2.2: EFL students' Paragraph Writing Practices\Performances

\begin{tabular}{lllllll}
\hline No Item & $\begin{array}{l}\text { Frequency/ } \\
\text { Percent }\end{array}$ & Always & Sometimes & Rarely & Never \\
\hline 2. & $\begin{array}{l}\text { How often do you practice (perform) } \\
\text { paragraph writing activities in EFL } \\
\text { classroom? }\end{array}$ & Frequency & 0 & 2 & 37 & 1 \\
& Percent & 0 & $5 \%$ & $92.5 \%$ & $2.5 \%$ \\
\hline
\end{tabular}

In the above table, item number 2 was prepared to collect data about the performance/practice of students' paragraph writing in the classroom. Out of 40 students $37(92.5 \%)$ of them said 'rarely', 2(5\%) of them said 
'sometimes' and $1(2.5 \%)$ of them said never. Nobody said 'always'. This indicated that the students were not practicing writing in the classroom based on the writing activities as given in their textbook. Andrews, (1999), states that writing is a skill acquired only through practice. It is, like dance and sport, an activity that could be improved only through practice. As the above analyzed data showed that, lack of practice was their serious problem.

Table 4.2.3: Analysis of Students' Ability on Using Three Parts of Paragraph Writing

\begin{tabular}{lllll}
\hline No & Item & $\begin{array}{l}\text { Frequency/ } \\
\text { Percent }\end{array}$ & Yes & No \\
\hline 3. & $\begin{array}{l}\text { Do you know the difference between topic sentence, supporting } \\
\text { sentences and concluding sentence in writing paragraph appropriately? }\end{array}$ & $\begin{array}{l}\text { Frequency } \\
\text { Percent }\end{array}$ & 10 & 30 \\
\hline
\end{tabular}

In the above table, out of 40 respondents 10(25\%) of them said 'Yes' whereas 30(75\%) of them said 'No'. This revealed that most students cannot write the paragraph which has the main three parts like topic, supporting and concluding sentences. In writing process, there should be an introduction with general ideas, supporting sentences with their detail, examples, illustrations, and concluding with short summaries to be said a paragraph. In line this, the result of document analysis also shown that more than $70 \%$ of the respondents could not write topic, supporting and concluding sentences appropriately. In short, students couldn't identify three main parts of the paragraph in writing.

Table 4.2.4: Analysis of Students Using Elements of a Good Paragraph in Writing

\begin{tabular}{|c|c|c|c|c|}
\hline No & Item & $\begin{array}{l}\text { Frequency/ } \\
\text { Percent }\end{array}$ & Yes & No \\
\hline \multirow[t]{2}{*}{4} & \multirow{2}{*}{$\begin{array}{l}\text { Can the problems of unity, coherence, and organization be the major } \\
\text { causes in writing paragraph? }\end{array}$} & Frequency & 4 & 36 \\
\hline & & Percent & $10 \%$ & $90 \%$ \\
\hline
\end{tabular}

Item number 4 was asked to check whether students can write well organized paragraphs or not using criteria of a good paragraph. Of 40 respondents only 2(5\%) of them said 'Yes' whereas 38(95\%) of them said 'No'. This showed that almost all students have no awareness and practice about writing a unified, coherent, and well organized paragraph. This means, they were poor in expressing their ideas in well-organized way.

Table 4.2.5: The Importance of Learning Paragraph Writing Skills before Writing the Final Version

\begin{tabular}{lllllll}
\hline No & Item & $\begin{array}{l}\text { Frequency/ } \\
\text { Percent }\end{array}$ & Always & Sometimes & Rarely & Never \\
\hline $\mathbf{5}$ & $\begin{array}{l}\text { How often do your English language teachers } \\
\text { teach you the steps/process of writing a good } \\
\text { paragraph before writing it? }\end{array}$ & Frequency & 0 & 2 & 4 & 34 \\
& Percent & 0 & $5 \%$ & $10 \%$ & $85 \%$ \\
\hline
\end{tabular}

Item number 5 was prepared to collect information to know how students practice the steps or process that should be exercised before writing a good paragraph. Out of 40 students $34(85 \%), 4(10 \%), 2(5 \%)$, and $0(0 \%)$ of them replied 'never,' 'rarely,' 'sometimes,' and always respectively. This indicated that almost all students could not learn and exercised the different steps and processes of writing paragraph. To conclude, the teachers were not giving the opportunity to practice writing in the actual classroom; they simply ordering the students to write a paragraph.

Table 4.2.6: Assessing Students' Believe on the Techniques and Strategies of EFL teachers use to improve their writing skills

\begin{tabular}{lllll}
\hline No & Item & Frequency/ Percent & Yes & No \\
\hline $\mathbf{6}$ & $\begin{array}{l}\text { Do you think the actual techniques/ strategies your English } \\
\text { language teachers use are sufficient to improve your paragraph } \\
\text { writing skills? }\end{array}$ & Percent & 2 & 38 \\
& $5 \%$ & $95 \%$ \\
\hline
\end{tabular}

In the above table, the item was prepared to check whether the actual techniques/ strategies teachers use to improve students' paragraph writing skill is sufficient or not. Out of 40 respondents $38(95 \%)$ of them said 'No' and $2(5 \%)$ replied 'Yes'. This showed the students were not interesting in the methods their teachers were using in the class to teach writing skill. This means, teachers were using tradition approach of teaching writing. To this effect, the students could not get the chance to improve their ability of writing as it could be. From this, the researcher concluded that the techniques/strategies that teachers were using to teach paragraph writing was not systematic and student centered or process oriented.

Table 4.2.7: Analyzing teachers' role in teaching paragraph writing skills

\begin{tabular}{lllll}
\hline No & Item & $\begin{array}{l}\text { Frequency/ } \\
\text { Percent }\end{array}$ & Yes & No \\
\hline 7 & $\begin{array}{l}\text { Do you think your teachers play their role to improve your } \\
\text { paragraph writing skills? }\end{array}$ & $\begin{array}{l}\text { Frequency } \\
\text { Percent }\end{array}$ & 4 & 36 \\
\hline
\end{tabular}

In the above table, item number 8 was used to check whether ELT teachers were playing their role to improve students' paragraph writing skills. Of the 40 students, $4(10 \%)$ of them said 'Yes' and $36(90 \%)$ of them 
said 'No'. As it is seen from the above result, most of the respondents said 'No'. This implies that English language teachers were not playing their role to enhance students writing skills which is one of the major factors why students are poor in paragraph writing skills.

\subsubsection{Causes of EFL Students' Paragraph Writing Problems}

The respondents were asked to identify factors which affect their writing performance. Accordingly they responded to it which is analyzed bellow.

Table 4.2.9.1: Causes of EFL Students' Paragraph Writing Problems

\begin{tabular}{|c|c|c|c|c|c|c|c|}
\hline No & $\begin{array}{l}\text { My problems of paragraph writing are } \\
\text { due to: }\end{array}$ & $\begin{array}{l}\text { Frequency/ } \\
\text { Percent }\end{array}$ & SA & $\mathbf{A}$ & $\mathbf{U N}$ & DA & SD \\
\hline \multirow[t]{2}{*}{1} & \multirow[t]{2}{*}{ lack of vocabulary } & Frequency & 38 & 2 & 0 & 0 & 0 \\
\hline & & Percent & $95 \%$ & $5 \%$ & 0 & 0 & 0 \\
\hline \multirow[t]{2}{*}{2} & \multirow[t]{2}{*}{ lack of organizing ideas } & Frequency & 28 & 9 & 0 & 3 & 0 \\
\hline & & Percent & $70 \%$ & $22.5 \%$ & 0 & $7.5 \%$ & 0 \\
\hline \multirow[t]{2}{*}{3} & \multirow[t]{2}{*}{ lack of using proper grammar } & Frequency & 22 & 13 & 0 & 5 & 0 \\
\hline & & Percent & $55 \%$ & $32.5 \%$ & 0 & $12.5 \%$ & 0 \\
\hline \multirow[t]{2}{*}{4} & \multirow[t]{2}{*}{ lack of teaching techniques } & Frequency & 36 & 2 & 0 & 2 & 0 \\
\hline & & Percent & $90 \%$ & $5 \%$ & 0 & $5 \%$ & 0 \\
\hline \multirow[t]{2}{*}{5} & \multirow[t]{2}{*}{ lack of practice } & Frequency & 36 & 4 & 0 & 0 & 0 \\
\hline & & Percent & $90 \%$ & $10 \%$ & 0 & 0 & 0 \\
\hline \multirow[t]{2}{*}{6} & \multirow[t]{2}{*}{ lack of motivation } & Frequency & 20 & 8 & 2 & 10 & 0 \\
\hline & & Percent & $50 \%$ & $20 \%$ & $5 \%$ & $25 \%$ & 0 \\
\hline \multirow[t]{2}{*}{7} & \multirow[t]{2}{*}{ shortage of time } & Frequency & 24 & 6 & 4 & 6 & 0 \\
\hline & & Percent & $60 \%$ & $15 \%$ & $10 \%$ & $15 \%$ & 0 \\
\hline \multirow[t]{2}{*}{8} & \multirow[t]{2}{*}{ lack of adequate feedback and assessment } & Frequency & 20 & 10 & 3 & 7 & 0 \\
\hline & & Percent & $50 \%$ & $25 \%$ & $7.5 \%$ & $17.5 \%$ & 0 \\
\hline
\end{tabular}

Key: $S A=$ Strongly Agree $A=$ Agree $U N=$ Undecided $D A=$ Disagree $S D=$ Strongly Disagree

As shown above, to check students' problems and causes of the problems in general, 8 questions were provided to respondents. The researcher categorized questions number 1,2 , and 3 , are the causes of the problems which are related to students; whereas, questions number $4,5,6,7$, and 8 were related to teacher's related problems.

\subsubsection{Students Related Problems}

In item 1, lack of vocabulary was the most serious problem. Here, out of 40 students $38(95 \%)$ said 'strongly agree' and the left $2(5 \%)$ of them said 'agree' with the lack of vocabulary is the main cause that for the students' problems in paragraph writing. Nobody replied 'undecided,' 'disagree' and 'strongly disagree'. From this data, the researcher generalized that all students have lack of using appropriate vocabulary in writing. Therefore, the most serious problems that affecting the students during paragraph writing was lack of using appropriate vocabulary. If they are not rich in vocabulary, they cannot write down something in their mind properly. To this effect, lack of using proper vocabulary was the first and the most serious causes of their incapable of writing a paragraph. In item 2 , out of 40 respondents $28(70 \%)$ of them said 'strongly agree' and $9(22.5 \%)$ of them said ' 'agree' whereas $3(7.5 \%)$ of them said 'disagree'. This showed that many students cannot organize their ideas in unified, coherent, and well organized ways. Few of them can write organized paragraph with minor problems. The same result of this one was shown (94\%) after the written paragraphs were analyzed through document analysis in the previous section. From the above data, lack writing well organized paragraph was the fourth factor that affecting students in writing paragraph. In item 3, of the respondents $22(55 \%)$ said 'strongly agree' and $13(32.5 \%)$ of them said 'agree' respectively, but 5(12.5\%) of them said 'disagree'. Clifford (1987) suggests that teachers should encourage students to focus on the message, ideas or thoughts they wish to convey rather than grammar, spelling, punctuation and others. This indicated that many students have the problem of using correct grammar in their writing. They couldn't proper grammar to express their ideas.

\subsubsection{Teachers Related Problems}

In item number $5,36(90 \%)$ of the respondents said 'strongly agree' $2(5 \%)$ said 'agree' and $2(5 \%)$ them replied disagree. Among the respondents, nobody said 'undecided', and 'strongly disagree'. Here almost all students replied strongly agree and agree, except two of them. This revealed that all students pointed to teachers. This means, teachers were not teaching appropriately to improve students' paragraph writing skills. The students didn't feel happy the strategies that teacher were using in EFL class. From the above analysis and discussion, the researcher conclude that the strategies and techniques that teachers were using in EFL class was the third major problem that affecting students' paragraph skills. Similarly, in item number 5, of 40 respondents 36(90\%) of them said 'strongly agree' and 4(10\%) of them said 'agree'. No one said 'undecided,' 'disagree' and strongly disagree.' This indicated that their teachers were not letting the students to practice as it is avail on their textbook. 
Without practicing, nobody can get experience and improve something in their mind. In line this, Andrews, (1999), states writing is a skill acquired only through practice. It is, like dance and sport, an activity that could be improved only through practice. To conclude, lack of practice was the second serious factors hindering their ability to write a good paragraph. Accordingly, in item number 6, out of all respondents, 20(50\%), 8(20\%), $2(5 \%)$, and $10(25 \%)$ of them replied 'strongly agree', 'agree' 'undecided' and 'disagree respectively. This implies that many teachers were not motivating or encouraging their students to be competent in writing. Some students replied as their teachers were motivating them during writing. Few students could not decide whether motivation was their problems or not. As to Atkinson (2002), the teacher does not have other choice except to try to wake learners' motivation. Motivation means a cluster of factor that 'energizes' the behavior and gives it direction. The above discussion indicated that lack of motivation was also one of the factors affecting students' paragraph writing skills.

Likewise, in item number 7 , out of the 40 respondents $24(60 \%), 6(15 \%), 4(10 \%)$ and $6(15 \%)$ replied 'strongly agree', 'agree', 'undecided' and 'disagree' respectively. In this case, more than $50 \%$ of them have shortage of time during writing a paragraph, but some students said the given time was not the major problem in writing. To support the above response, Kroll (1990: 140) claims that time may also be a key factor in producing a text with full of control over organization and coherence. In addition, many students and teachers feel that writing under time pressure is a very unnatural situation and perhaps cannot lead them to produce compositions that are truly representative of their capabilities. From the analysis of the above data, the shortage of the given time was also problem in writing. In item number 8, out of the 47 respondents $20(50 \%), 10(25 \%), 3(7.5 \%)$ and $7(17.5 \%)$ of the respondents replied 'strongly agree', 'agree', 'undecided' and 'disagree' respectively. The result revealed that English language teachers were not giving appropriate feedback for students. In short, this can affect students' performance of writing their ideas in attention. If there is no feedback, students do it carelessly. To collect more reliable information about the problems of students' paragraph writing, the students were asked 2 open ended questions. In the first item, the students were asked to list their problems according to their problems difficulty. As the collected data indicated, all students have various problems during writing paragraphs. Among 40 students, nobody was good at in writing process. The students said that they have several problems during writing their paragraphs. As they said many students had the problems of using proper vocabulary, organizing their ideas, writing topic, supporting and concluding sentences. According to some students' point of view, the other problems they made in writing paragraph were lack of grammar, spelling error, and using punctuation marks. Here, many students mentioned the same and nearly the same ideas with the following responses. For example S5 said, "My first big problem writing is lack of using vocabulary. When my give writing paragraph, I always think the word I used to write my idea. I cannot have use words express the things. The second problem I canot organizing ideas. I canot identify topic sentences, supporting sentences and conclusion in a paragraph. It confusion me. My other problems are error spelling and puntution marks. ” From this, the researcher critically evaluated and checked the responses which were given by 40 students. Then after he concluded that the serious problems that students made during writing their paragraphs were lack of using appropriate vocabulary, lack organizing their ideas, the problem of identifying topic, supporting and concluding sentences and grammar usage. In addition, they cannot spell words and use punctuation marks correctly.

In the second item, the question was asked to gather information about the causes of EFL students' paragraph writing problems to support the causes mentioned in the above table. Of 40 respondents, many of them gave the same responses. According to their responses, the major reasons that hinder their paragraph writing were lack of vocabulary they used, lack of practice they perform in their actual classroom, lack of organizing their ideas, lack of teaching techniques and lack appropriate feedback respectively. Some the respondents wrote as their reasons that affect their paragraph writing were lack of spelling words correctly, lack of grammar usage and lack of the given time respectively.

After analyzing and evaluating the written responses carefully, the result of data showed that the major problems were using appropriate vocabulary, lack of organizing ideas, inappropriate teaching methods teachers. As some students responses, lack of grammar usage, error of spelling and shortage of the given were also the major reasons for some them.

\subsection{Analysis of Classroom Observation}

The third instruments that the researcher used to collect data from different angles were classroom observation. The researcher employed this instrument to collect real and actual performance during the actual classroom is ongoing. Based on the plan, the researcher critically observed each section during the actual classroom was ongoing. To observe the ongoing lesson, six (6) questions were employed as classroom observation checklist. 
Table 4.3.1: Results of Classroom Observation Checklist

No During teaching paragraph writing does:
1 English language teacher gives familiar, clear and
relevant topic with the students' knowledge?

2 English language teacher tells the students the steps of paragraph writing before they start it?

3 English language teacher encourages students during writing the paragraph in EFL class?

4 English language teacher uses proper approach to improve the students' writing skills?

$5 \quad$ English language teacher uses appropriate techniques to promote students' writing skills?

6 English language teacher gives enough time for writing?

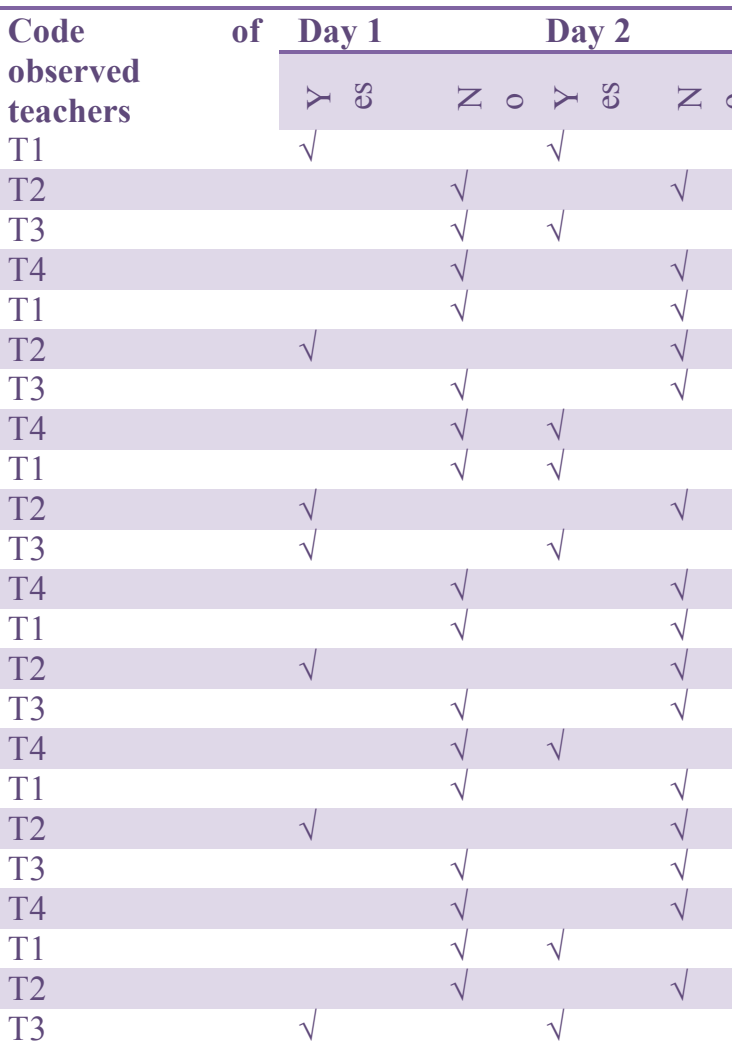

Key: T1, T2, T3, and T4 represent Teacher 1, Teacher 2, Teacher 3 and Teacher 4 respectively.

As shown in table 4.3.1, item 1, among the four teachers observed, one of them let the students to select appropriate topic themselves. Three of them gave relevant and clear topics for the students because they are familiar with these topics. As it can be shown, based on their teaching experience, teachers attempted to give clear, easy and relevant topics for them. This showed that many teachers gave different titles for their students. In item 2, Of 4 teachers, only two teachers told them as they have to write the first draft and then write the last paragraph in second day session. Two of them didn't tell the students any steps to be followed before writing in both days' sessions. From this, the researcher generalized, the teachers were not teaching the steps or process of paragraph writing to promote students' writing skills before submitting the final version. In item 3, out of 4 teachers, two of them tried to encourage their students by moving between them during they were writing the paragraph. The left two teachers were not encouraging their students to practice writing. They simply ordered students as they are familiar with the language to write instead of practice. From this data, most of the time, teachers were not motivating their students as it could. This can be a factor affecting students' writing skills. In item 4, during teaching paragraph writing, all teachers didn't use the approach that improves students' writing skills. They simply entered the class and told them as they have to write a good paragraph based on the topics given. Two teachers told them as it could be marked out $10 \%$ whereas the left two teachers told them as it could be marked out of 5\%. This implies that many teachers were not using the right approaches to promote their students writing skills. They never let them to practice and exercise writing; rather they were rushing to mark. So, the teaching approaches teachers were using to improve students writing skill was one of the major problems. In item 5, of the four teachers only one teacher taught them as they have to write the first draft and then write the final version. He told them, if they wrote good paragraph, it would be marked, if not, it would not be. Three of the respondents simply entered the class and ordered them to write a paragraph according to the given topics on the chalk board. To conclude, teachers were not trying their best to promote students writing skills. So, this was also another serious problem affecting students' paragraph skills. In item 6, of the four teachers 2 of them gave the task in the class and collected after 35 minutes in the classroom in their first day sessions. They told them as it could be marked out of 10 marks. But, two teachers couldn't collect the paper with in the given time. One teacher told them as it could be submitted in the next session because most of them didn't finish it. The two teachers let the students to write the paragraph within 25 minutes. For this reason, the teachers could not collect the papers; one teacher postponed to next session whereas the second teacher added 10 minutes. So, this shows that the allotted time was not sufficient to do writing activities for some students. As the result indicates, shortage of the given time was one factor. 


\subsection{Analysis, Teachers' Interview Data}

In this section, the researcher prepared about nine (9) interview questions based on the objectives of the study. Accordingly, in the first interview question, the researcher asked the interviewees to know whether students face problems through writing a paragraph or not. All interviewees replied and agreed that all students encountered various problems in writing a paragraph. All of them said 'Yes'. This means, all students have problems in paragraph writing.

In the second interview question, the interviewer asked the interviewees, to collect data about the problems that students make during writing. The respondents replied almost the same responses. They said the problems that students commit in writing process were repetition of words or lack of choosing appropriate words, lack of organizing ideas, lack of identifying topic sentence, supporting sentences and concluding sentence accordingly. The other problems they mentioned were lack of using correct grammar, spelling error and punctuation problems. For example, T2 said, "during paragraphs they made problems like lack of using appropriate vocabulary, lack of writing organized, unified and coherent paragraph. The other problems were spelling errors, lack of word choice, lack of using appropriate punctuation and so forth."

The analysis of the above data shows that students have serious problems in using appropriate words or vocabulary and organizing their ideas during writing. So, lack of vocabulary, lack of organizing ideas were their major problems in writing paragraph.

In the third interview question, the researcher asked to identify the causes of the problems. Out of 4 teachers, 2 of them replied the major causes that affect students' paragraph writing skills were lack of using appropriate vocabulary and lack of practice. In addition, the given time which was allowed to practice was too short. For this reason, we couldn't apply all strategies to promote their writing skills. So, this can be the serious problems could be solved. Two of the respondents said that the strategies/ techniques they were using were too traditional. So, the serious causes of writing unorganized paragraph were the method they were employing while teaching it. To support this, Leki (1991) claims that learners of English as a second or foreign language face problems of exploring ideas and thought to communicate with others could be because of the traditional methods teachers use to teach writing for spelling, punctuation, and mastering grammar. In line this, T3 replied, "I think their problems are due to lack of using appropriate vocabulary, lack of practice in and outside of the school, the methods we use to teach writing skills and their motivation to do writing tasks." The analysis of the above data reveals that lack of vocabulary, practice and inappropriate teaching methods were the first, second and third causes of students' problems in paragraph writing respectively.

In the fourth interview question, the researcher asked to check and evaluate how teachers give opportunity to their students to improve their writing skills. All teachers agreed on that they were not applying writing activities as it is available on their textbook in the classroom.T1, T3 \& T4 said that it was too difficult to apply all writing activities on the students' textbook in the classroom. The reason was its time consuming, it was subjective to mark and grade, it was boring to teach and it needs small number of students in the classroom, but we have more than 40 students in a classroom. So, applying such writing activities in the classroom was impossible in our school context they said. T2 said, "since their text book was bulky to cover within a year, we have to rush to finish it. Another reason was that the numbers of students in the classroom were large and subjectivity of writing, so it was hard to do it." From the above analysis, the researcher concluded that the teachers were not teaching them writing skills for the above mentioned reasons. This means that teachers were not teaching writing as it is available in their textbook and not trying their best to enhance students' writing skills.

The fifth interview question was designed to analyze how teachers give the chance to practice writing in the classroom. Of the four respondents, 1 teacher replied that students didn't like to perform or participate in writing activity. If writing activities given for them, they simply wait only the selected student to write from members. 2 teachers replied, almost all students were not interested to participate in writing activities. Most students preferred to do as an assignment instead of writing in the classroom. For this reason, they let the students to practice rarely, sometimes, and twice per semester. For instance, T4 replied, "Most of the time I gave them assignment instead of class work due to shortage of time and to cover the portion on time. So, I rarely let them to practice." As their responses, the students didn't feel happy when writing a paragraph was given. For this reason, to save time usually they gave them assignment instead of writing in the classroom. From this discussion, the researcher conclude, teachers were not giving the chance to practice writing paragraph in the classroom. This indicated students were not practicing or performing writing activities in the classroom. So, lack of practicing is the most serious problem affecting their writing skills.

The sixth interview question was designed to analysis whether the techniques that teacher were using during teaching writing skills was appropriate for students or not. Of 4 the respondents of them said the methods they were using to teach writing were not this much appropriate for students. They reason out that to cover the portion and save time, we were not using as helpful methods as possible to promote students' writing skills. For instance T4 said, "I usually use product approach, sometimes I used process approach. When I use process approach, it needs more than two periods to teach and perform paragraph writing." This indicated that the methods or 
strategies that teachers were using directly affected the students writing skill. As to Grisham and Wolsey (2011), "for many elementary and secondary teachers, writing is the area of language arts that they feel themselves least prepared to teach well" (p.348). So, the analysis shows that ELT failed in using apt teaching methods, so it is the other serious problems in writing.

In the seventh interview question, the interviewer asked to analyze whether teachers teach the step or process of writing paragraph or not. Of the 4 teachers, 2 of them said they didn't teach any steps about paragraph writing in the classroom. According to their responses, the students cannot follow and apply the steps in a period (45'), so most of the time they did it at home as an assignment. The left 2 teachers replied as they taught the steps orally and in written forms, but there were no application in the classroom because of shortage of the given time and number of the students in the class.

From the above discussion, the researcher concluded that due to shortage of time and numbers of the students in the classroom teachers were not giving due attention about teaching the steps of paragraph writing in the actual classroom.

In interview question item 8 , the researcher raised whether students can write well organized, unified, and coherent paragraph. On this issue, all four teachers replied the same ideas. They said that almost all students couldn't write well organized, unified and coherent paragraph. As they said, only few students attempted to write a good paragraph with minor problems. According to their responses, due to lack of vocabulary, lack of practice, lack of grammar and inappropriate methods that teachers use students' ability of writing paragraph was highly affected.

The last interview question was designed to assess about teachers role in teaching writing in the classroom. All respondents replied that many of them were not playing their role as it could be. Brown (2000, p. 340). The role of the teacher has to be one of facilitator and coach, not an authoritative arbiter. As a facilitator, the teacher offers guidance in helping students to engage in the thinking process of composing but, in a spirit of respect for student opinion, must not impose his or her thoughts on student writing. The paragraphs written by students have various problems like illegibility, grammar, organization, spelling, punctuation and clarity. The teachers in the interview also claimed that they were not playing their roles as a teacher. Students' weakness in writing paragraph emanated from teachers fault in providing proper care.

\section{FINDINGS, CONCLUSIONS AND RECOMMENDATIONS}

\subsection{Findings}

On the bases of the data analysis made, the following findings were obtained:

1. With regards to the problems EFL students face in paragraph writing were lack of organization of their ideas, lack of writing unified, coherent, adequate paragraph, lack of awareness about three main parts of the paragraph, and mechanical problems like; spelling, word choice, grammar, and punctuation were identified as the major ones.

2. The second objective is the causes of students' problems in writing paragraph.' major causes of the problems were lack of using appropriate vocabularies, lack of regular practice/performance in the classroom, and lack of grammar usage.

3. With regards to the third objective, the data analysis revealed that ELT teachers under the study were not using appropriate teaching approaches, methods, techniques and strategies to improve students' writing skills.

\subsection{Conclusions}

Based on the overall summaries made above, the following conclusions are drawn.

* Though writing needs to be well organized and clear for the reader, almost all students wrote illogical, inadequate, unorganized and incoherent paragraphs. As observed from written paragraphs, students couldn't write the paragraphs which have unity, coherence, clarity, adequate development and organization. Most of their paragraphs have no clear topic sentence, supporting sentences and concluding sentence as well. In addition, they couldn't spell words, choose suitable words, use correct grammar and use appropriate transitional words. This revealed that students have not been practicing writing in and outside of the classroom.

* The major causes of EFL students' paragraph writing problems were lack of using right vocabulary in their writing, lack of confidence, lack of interest to practice writing, short of time to practice and lack of teachers' feedback.

* During EFL teachers were teaching writing skills, students didn't feel happy and interesting in the classroom. They didn't actively participate during writing activities given due to lack of word choice, lack of grammar, lack of spelling and organization.

* English language teachers failed to use appropriate techniques, strategies and methodologies to improve students' paragraph writing skills during teaching writing. They did not play their roles to promote 
students' paragraph writing skills. During teaching writing paragraph, they didn't teach them the steps or process of writing paragraph before they start to write. They simply ordered them to write a paragraph within the allowed time.

\subsection{Recommendations}

Based on the conclusions drawn, the following recommendations have been suggested.

* Students should identify their own writing problems and do their best to improve their writing skills in addition to their teachers support.

* English language teachers should identify students' writing problems and should use different strategies to slash the same. In line to this, the teachers should teach students how well organized paragraph can be written. In addition, they should give awareness about three parts of paragraph writing such as topic sentence, supporting sentences and concluding sentence in detail. They should follow their application in regular ways.

* English language teachers should pay due attention to writing skill to be practiced seriously in writing class. They should let their students to practice and improve their vocabularies through practice. They also should give sufficient time and feedback for students. From the lower classes writing skill should be practiced as other skills.

* English language teachers should read different references which improve their teaching methods and strategies to enhance their students' writing skills. Likewise, they should employ as many techniques, strategies and methods as possible to improve students' writing skills. In addition, ELT teachers should teach students the process of writing which could be employed students they started writing, and should follow its execution attentively.

* TTI need to develop additional courses for EFL teachers which focus on how to teach writing skills at high schools level.

\section{References}

Alice Oshima and Ann Hogue (1996), Writing Academic English, (New York: Addison Wesley Publishing Company.

Brown, H. Douglas (2007), Principles of Language Learning and Teaching: Fifth Edition. United States of America: Pearson Education, Inc.

Byrne, D. (1988). Teaching Writing Skills. London: Longman Press.

Celce-Murcia,M. (2001). Teaching English as a second or foreign language (3rd ed). USA: Heinle\&Heinle.

Clifford, M. (1987). Using Spoken and Written English. Kharma, N.(1986). Composing Problem. Diagnosis and remedy English teaching, forum.

Dula Debela (2017). Factor Affecting the Parctice of Grade 10 Students' paragraph Writing Skills. A case in Miesso Secondary School.Haramaya University.

Jeremy Harmer (2001), 'How to Teach Writing, (England: Pearson Education Limited.

Kalof, Dan and Deitz.(2008). Essentials of Social Research.Open University press.

Kharma, N. (1986). Composing Problem. Diagnosis and remedy English teaching, forum.

Leki, I. (1991). Teaching Second Language Writing: Where We Seem to Be: English Teaching Forum.

Oshima, A and Hogue (2007).Writing academic English. Pearson Education: Longman

Pincas, A. (1982). Teaching English Writing. London: MacMillan.

Raimes, A. (1983). Techniques in teaching writing. Oxford, England: University Press.

Tyner, E. (1987).College Writing Basics: A Progressive Approach. Belmont. Wands worth Publishing Company. 